\title{
Study of Value Investment Under Consumer Cyclical Industry
}

\author{
Jinjing $\mathrm{He}^{1, *, a, \uparrow}$, Haixin $\mathrm{He}^{2, *, b, \dagger}$ \\ ${ }^{1}$ The Winchendon School, Winchendon, MA, US \\ ${ }^{2}$ The Winchendon School, Winchendon, MA, US \\ *Corresponding author.Email: ${ }^{a}$ Jinjinghe22@winchendon.org, ${ }^{b}$ haixinhe22@winchendon.org
}

${ }^{\top}$ These authors contributed equally

\section{ABSTRACT}

This research aims to look for each stocks' feature and whether the stock worth to invest, which makes the stock clear, comprehensible, and find out the fit stocks of investors. This paper takes three enterprises in the Consumer cyclical industry as the research object, takes financial data and stock data as the research data, and uses the index analysis method to carry out a theoretical study on value investing. The research results show that, firstly, from the perspective of risk, Tesla has the highest risk value; second, from profitability, JD has the most advantage in profitability. Third, in the market index, we find that JD is the most stable. We listed three companies --JD, McDonald, and Tesla--and after analysis, we can get the result that JD would be the one in three stocks that most fit in value investment. The contribution of this paper would be the form of analysis in basic 3 main sectors of indexes to figure out the one most fit people themselves investing style or the one that wins the comparison and most worth to invest.

Keywords: Value invest, Consumer cyclical industry (JD, McDonald, Tesla), Index analysis

\section{INTRODUCTION}

Nowadays, finance market develops rapidly and relates closely to people's daily life. In 2021, a pandemic area that almost every industry is declined. How to invest is always a popular question because investing becomes an essential method rather than saving money and growing your money, although now during the decline. Many types of investment are invented, such as value investors, which is almost the most popular way Watt Buffet. Inside the value investment, people use many methods to evaluate and analyze stocks to achieve their goals. Some researchers used theoretical research, empirical comparison, and research to study the value investment strategy problems of a pirate equity investment fund company. His research result shows that investment and its leading disadvantage can be solved by value investment strategy and can use invest strategy forecasting different types of the company's current stock price [1]. Some researcher came up the idea of combining Chinese stock market with value invest. By sorting the development of western countries and combining with the domestic value investment environment, he explained the concept and the methodology of value investment. Meanwhile, he analyzed two valuation methods, the absolute value of the assessment Model and relative value of assessment which helps to compare the value investment in China. As a result, he synthesized the actual Chinese stock market and the specific example to get his conclusion [2].

Another researcher studied analyzing listed companies in the electric power industry to judge and choose the potential valuable companies' stocks rather than overvalued stocks. The author picked 68 stocks from the industry to analyze from the macro policy environment, industrial background, and pecuniary conditions to get the worth of this industry. It used SPSS to calculate14 sectors from debt-paying ability, profitability, operating ability, and profitability through dimension reduction, correlation test, and comprehensive score and do the analysis. Then it listed the companies' annual financial loss and non-loss as analytic targets to make a logistic regression model and then test the actual result of the logistic model. Finally, given the forecast results of financial warning, the author gave the relative investment advice [3].

To see all of the papers above contents, they researched whether the specific example object(s) or in a macro side to analyze the whole industry. The specific example object(s) would have deeper researches and more 
specific analysis of the company or the stock. Still, it may lose some views in general about the whole industry, so it is needed to combine the theory or actual status of the industry. Also, the big analysis would lose some detail and can't give more specific things. It is a decent way to combine two ways of analyzing listed companies in the same or similar industry, which pick some targets to make a microscopical analysis. However, there is a problem that there are various objects which are too many and needed spending plenty of time to research, observe, list, and analyze them. It would be a long period to collect the data and set up models, then another long period to analyze and focus on the research topic conclusion. Also, most of them are focus on one industry which is a good thing to study without any distractions. Still, there is no comparison with others that cannot show the truth of the stock market because people would not focus only on one industry to buy their stocks. It is more realistic to compare different stocks in different industries and then find out the most valuable and profitable ones.

The study in this paper would focus on only 3 companies' stocks in two industries, and both are very typical examples. It would be the first focus on analysis and then comparing the 3 stocks to get which one has the best ability in these 3 stocks through data from 3 sides, risk, profit, and market value.

\section{DATA AND METHODS}

\subsection{Data}

Our data is come from Yahoo Finance and calculate and analyze by us. We chose three types of data, and they are. We collect the data for 12 months, and the data is ratios that can affect our types of data. And we have chosen 3 stocks, and I am going to write the basic information of these three companies.

JD, China self-operated electric business enterprise, founder Liu Qiangdong, chairman and chief executive officer of, JD group. Its JD shopping mall, JD finance, pat Network, JD intelligence, $\mathrm{O} 2 \mathrm{O}$, and overseas business division. In 2013, a virtual operator licence was officially granted. It was officially listed on the Nasdaq Stock Exchange in May 2014. In July 2015, JD selected the Nasdaq 100 index and the Nasdaq 100 average weighted index with high growth reached a deep strategic cooperation with WALL-MART in June 2016 and merged Shop No. 1 into JD.

Tesla, an American electric vehicle and energy company, produces and sells electric vehicles, solar panels, and energy storage equipment. Headquartered in Palo Ato, founded on July 1, 2003, by Martin Abehard and Mark Tarpenning, the founder named the company "Tesla Motors" to commemorate physicist Nicola Tesla. In 2004, Elon Musk entered the company and led the A round of financing.

McDonald's, which is a large multinational restaurant in the world. It was founded in 1955 in Chicago, USA. It has about 30 thousand branches in the world. The main selling hamburgers, fries, fried chicken, soft drinks, ice products, salad, fruit, and other fast food.

\subsection{Method}

There is a lot of ratios, so I am going to pick few representative ratios to explain. The debt ratio is a financial ratio that measures the extent of a company's leverage. The debt ratio is defined as the ratio of total debt to total assets, Debt to asset ratio $=($ Total liabilities $) /$ (Total assets). With a ratio greater than 1 , the company has more liabilities than assets [4]. A high ratio also indicates that a company may be putting itself at risk of default on its loans if interest rates rise suddenly. A ratio below 1 translates to the fact that a greater portion of a company's assets is funded by equity. The Profit margin represents profitability, and it means one of the common profit margins that measure the profitability of a company or business, and the profit margin has three metric which are Gross Profit Margin Gross Profit, operating Profit Margin, and their formula are Gross Profit Margin = Gross Profit $/$ Revenue x 100, Operating Profit Margin = Operating Profit / Revenue x 100 and Net Profit Margin $=$ Net Income / Revenue x 100[5]. It represents the percentage of sales turnover to profit. In short, the percentage figure represents how many cents the business has created for each dollar sold. There are several types of profit margins. However, in daily use, it usually refers to the net profit rate, that is, the bottom line of all other expenses deducted from the company's income [6]. And the representative of the market value is the PE ratio, which is defined as the ratio for valuing a company that measures its current share price relative to its per-share earnings. And the price-toearnings ratio is also sometimes known as the price multiple or the earnings multiple [7]. Investors and analysts use $\mathrm{P} / \mathrm{E}$ ratios to determine the relative value of a company's shares in an apples-to-apples comparison. In general, a high $\mathrm{P} / \mathrm{E}$ suggests that investors are expecting higher earnings growth in the future compared to companies with a lower $\mathrm{P} / \mathrm{E}$. A low $\mathrm{P} / \mathrm{E}$ can indicate either that a company may currently be undervalued or that the company is doing exceptionally well relative to its past trends. 
Table1. Stock Data

\begin{tabular}{|c|c|c|c|}
\hline & JD & McDonald & Tesla \\
\hline Risk & $\begin{array}{l}\text { Debt ratio: } 0.72 \% \\
\text { D/E ratio: } 0.15 \% \\
\text { Current ratio: } 1.02 \% \\
\text { Quick ratio: } 1 \\
\text { Beta: } 0.83\end{array}$ & $\begin{array}{l}\text { Debt ratio: } 0.97 \\
\text { D/E ratio: }-6.57 \\
\text { Current ratio: } 1.01 \\
\text { Quick ratio: } 1.00 \\
\text { Beta: } 0.62\end{array}$ & $\begin{array}{l}\text { Debt ratio: } 0.25 \\
\text { D/E ratio: } 0.57 \\
\text { Current ratio: } 1.88 \\
\text { Quick ratio: } 1.59 \\
\text { Beta: } 2.06\end{array}$ \\
\hline Profit margin & $\begin{array}{l}\text { Profit margin: } 6.62 \% \\
\text { ROA: } 1.96 \% \\
\text { ROE: } 30.62 \% \\
\text { Receivable turnover: } \\
43.689 \\
\text { Total Asset } \\
2.317\end{array}$ & $\begin{array}{l}\text { Profit margin: } 24.63 \% \\
\text { ROA: } 8.89 \% \\
\text { ROE: }-0.60 \% \\
\text { Receivable turnover: } 9.10 \\
\text { Total Asset turnover: } 0.36\end{array}$ & $\begin{array}{l}\text { Profit margin: } 2.29 \% \\
\text { ROA: } 2.82 \% \\
\text { ROE: } 5.42 \% \\
\text { Receivable turnover: } 9.10 \\
\text { Total Asset turnover: } 0.36\end{array}$ \\
\hline Market value & $\begin{array}{l}\text { PE ratio: } 17.18 \\
\text { PEG ratio: } 55.3 \\
\text { P/B ratio: } 4.37\end{array}$ & $\begin{array}{l}\text { PE ratio: } 35.69 \\
\text { PEG ratio: } 1.45 \\
\text { P/B ratio: }-21.44\end{array}$ & $\begin{array}{l}\text { PE ratio: } 966.73 \\
\text { PEG ratio: } 4.95 \\
\text { P/B ratio: } 26.72\end{array}$ \\
\hline
\end{tabular}

\section{ANALYSIS}

After the text edit has been completed, the paper is ready for the template. Duplicate the template file by using the Save As command and use the naming convention prescribed by your conference for the name of your paper. In this newly created file, highlight all of the contents and import your prepared text file. You are now ready to style your paper; use the scroll-down window on the MS Word Formatting toolbar's left.

\subsection{Risk}

Tesla has the least debt ratio and highest $\mathrm{D} / \mathrm{E}$ ratio, so Tesla has the least debt and three stocks. As we see, McDonald's has the lowest Total asset/Total equity. Still, it is nothing if the ratio is lower than 0 , so the $\mathrm{JD}$ is relatively minimum, but it is also very high. Tesla's current ratio and quick ratio are the highest. Otherwise, JD and McDonald's be roughly the same. So they are adorable for the short-term debt. JD and McDonald's Beta were lower than one, which means their security is theoretically less volatile than the market and tend to move more slowly than market averages. Tesla was much higher than them. Its Beta is 2.06, so it is a bigger one, so this stock's security price is theoretically more volatile than the market. This indicates that adding the stock to a portfolio will increase the portfolio's risk and increase its expected return. So after the analysis, Tesla is the riskiest one, and JD follows, and the last one is McDonald's.

\subsection{Profitability and Turnover Ability}

To see their representations on profitability and ability turnover, the most obvious one to see the company's profit, profit margin, JD is $6.62 \%$, Tesla is $2.29 \%$, and McDonald is $24.63 \%$. So, the McDonald's has the strongest power to earn money and won profits for its whole business running, and Tesla has the weakest power to get more profits, and it could be the high cost of producing products. Shareholders always need to check their benefits from buying this stock. Rather than the price growth of the stock, another way shareholders earning money is the dividends that the company could reply to them. Therefore, ROE is a ratio that shareholders should focus on to help evaluate the investable of the company. JD has $30.62 \%$, Tesla has $5.42 \%$, and McDonald's has $-0.60 \%$, as the data, at this point, McDonald would have the least revenue feedback to shareholders, and JD has the highest revenue to give back. Comparing these three stocks, they have big differences in ROE that JD has higher than $25 \%$, but McDonald has a negative one, and Tesla has a single digit, so JD has a kind of absolute advantage here. For ROA, a ratio that can show the company's profitability on making profits from the amount of its whole asset, and JD has $1.96 \%$, Tesla has $2.82 \%$, and McDonald has $8.89 \%$. They have similar amounts of ROA that, to check macroscopically, they all cannot make a lot of money compared with its asset. However, McDonald's has the highest number on it.

Next to focus on the turnover ratios, first is the inventory turnover, JD has 10.219, Tesla has 6.07, and McDonald has 185.04. As a result, McDonald's has the best ability to run out its inventory and good representation on its production and sales recovery, and Tesla has only 6.07, a lower representative on selling and inventory turnover ability. The second one is the receivable turnover that can show its capacity to turn its received money into cash flow. JD has 43.689 , the highest one. Tesla is 16.72, and McDonald's is 9.10, so a condition is the discrepancy of the inventory sales ability and the ability to turn to receive into cash for McDonald. It has a high ability to sell inventory, but it cannot turn its receive into cash. In conclusion, McDonald's has the highest power on profitability, but it has the relative lower reply to its shareholders and its own business running. 


\subsection{Market Value}

The third sector is the market value, and there are PE ratio, $\mathrm{PEG}$ ratio, and $\mathrm{P} / \mathrm{B}$ ratio inside it. $\mathrm{PE}$ ratio is a ratio that can evaluate the price of the stock. JD and McDonald have a common number of 17.18 and 35.69, but Tesla has an irregular number of 966.73, so Tesla is overvalued based on this ratio shows. PEG ratio is a development base on PE ratio, which can forecast the future profit growth rate. JD has 55.3, Tesla has 4.95, and McDonald's has 1.45. Therefore, McDonald would be the most stable one, and JD would be expected to grow a lot. $\mathrm{P} / \mathrm{B}$ ratio can determine whether it is worth investing the stock, that if it is low, it would be worth investing. JD is 4.37. Tesla is 26.72, and McDonald's is -21.44. As the data showed, JD would be the most worthful one, and McDonald's would not be a good choice because of its negative $\mathrm{P} / \mathrm{B}$ ratio, showing its debt may be more than its asset. To sum up, JD may be the one that most fits and represent best in value investment because of its lower stock price and PE ratio, and relatively lower risk, and good profitability. Tesla is a special one with the highest Beta and $\mathrm{PE}$ ratio, which is most risky and most challenge and potential; in the opposite, McDonald is the most stable one although it has more debt on and a kind of great profitability.

\section{CONCLUSION}

In conclusion, we listed three companies --JD, McDonald, and Tesla--and after analysis, we can get the result that JD would be the one in three most fit in value investing. Tesla would be suggested to people who can afford higher risky and want to receive higher profit possibility; McDonald would be suggested to people who focus on stable value and profit from a long-term investment. Value investing is a famous type of investment in modern times that Warren Buffet uses. It is appropriated to investors who have time but less principal and willing to find and focus on the stocks to find the stocks being undervalued and invest it. Propaedeutic investors can focus on these three parts to analyze the stocks and the companies to filter out which are good and bad. The ratios we used in this paper are very basic ratios, too, and they could be found on Yahoo Finance to get the easiest way to search all the ratios and information of stocks. It is suggested to try investing base on the index analysis and the ratios in this paper, which can be easily used by anyone. Base on the formulas of each ratio, audiences can fill the data in to get the ratios. As the works in this paper, audiences can analyze by themselves and pick some stocks researching, analyzing, and investing.

The contribution of this paper would be the form of analysis in basic 3 main sectors of indexes to figure out the one most fit people themselves investing style or the one that wins the comparison and most worth to invest. For companies, it should be focused the profit margin, especially the PE ratio, as an essential index for value investing, showing a company's potential. For individual investors, the risky sector would be recommended as the part being most focus on. It bases on different kind of people, for example, audacious investors can pick some stocks has lower PE ratio but higher Beta with many other indexes doing good that can be a risky but high potential stock; for investors who wants less risky and also expect fewer profit can focus on the stocks having lower Beta and other risk ratios and put in a long-term investment. Value investing can be various by combining many types of analysis of different indexes to fit different types of investors. Therefore, investors could try the methods in this paper to find out the one stock or investment most suitable.

\section{REFERENCES}

[1] Xiao Zhicheng. Research on the Value Investment Strategy of a Private Equity Investment Fund Company [D]. Huazhong University of Science and Technology, 2019

[2] Liang Yahui. Research on Stock Value Investment [D]. Jilin University, 2015.

[3] Chen Wenan. Analysis on Value Investment of Listed Companies in Power Industry [D]. Anhui Agricultural University, 2019.

[4] Ross, S. A., Westerfield, R., \& Jordan, B. D. (2008). Fundamentals of corporate finance. Tata McGraw-Hill Education.

[5] Min Cai, \& Lijun Wang. (2019). Research on EPS of Kweichow Moutai. Journal of Jilin Engineering Normal University, 035(008), 83-85.

[6] Jing Lu, \& Gang Liao. (2002). The Comparison of PE Ratio,PB,Free Cash Flow Multiplier and Portfolio Return. Economic Management, 000(014), 57-62.

[7] HALL, A.D. (2003). Introduction to Stock Investment. China Financial Publishing House.

[8] Egam, Gerald EY, Ventje Ilat, and Sonny Pangerapan. "Pengaruh Return on Asset (ROA), Return on Equity (ROE), Net Profit Margin (NPM), dan Earning Per Share (EPS) terhadap Harga Saham Perusahaan yang Tergabung dalam Indeks LQ45 di Bursa Efek Indonesia Periode Tahun 2013-2015." Jurnal EMBA: Jurnal Riset Ekonomi, Manajemen, Bisnis dan Akuntansi 5.1 (2017). 